\title{
On synonymy of linyphiid spiders of the Russian fauna (Arachnida: Aranei: Linyphiidae). 1
}

\author{
О синонимии пауков-линифиид фауны России \\ (Arachnida: Aranei: Linyphiidae). 1
}

\begin{abstract}
Andrei V. Tanasevitch
A.B. Танасевич

Centre for Forest Ecology and Production, Russian Academy of Sciences, Profsoyuznaya Str. 84/32, Moscow 117997 Russia. E-mail: andtan@mail.ru

Центр по проблемам экологии и продуктивности лесов РАН, Профсоюзная ул. 84/32, Москва 117997 Россия. E-mail: andtan@mail.ru
\end{abstract}

KEY WORDS: Spiders, Linyphiidae, new synonym, new combination, Russian fauna.

КЛЮЧЕВЫЕ СЛОВА: Пауки, Linyphiidae, новый синоним, новая комбинация, фауна России.

ABSTRACT. Seven new synonyms are established for the Russian fauna: Agyneta yakutsaxatilis Marusik et Koponen, 2002, syn.n. = Agyneta amersaxatilis Saaristo et Koponen, 1998; Bolyphantes palaeformis (Tanasevitch, 1989), syn.n. = Bolyphantes bipartitus (Tanasevitch, 1989), both comb.n. (ex Lepthyphantes Menge, 1866); Epigytholus tuvensis Tanasevitch, 1996, syn.n. = Epigytholus kaszabi (Wunderlich, 1995), comb.n. (ex Lepthyphantes); Hybauchenidium holmi Marusik, 1988, syn.n. = Hybauchenidium aquilonare (L. Koch, 1879); Poeciloneta yanensis Marusik et Koponen, 2002, syn.n. = Poeciloneta variegata (Blackwall, 1841); Savignia nenilini Marusik, 1988, syn.n. = Savignia birostra (Chamberlin et Ivie, 1947); Walckenaerianus aemonicum (Deltshev, 2005), comb.n. (ex Hypomma Dahl, 1886), syn.n. = Walckenaerianus esyunini Tanasevitch, 2004. W. esyunini is recorded from the Altayan fauna for the first time.

РЕЗЮМЕ. В фауне пауков-линифиид России установлено семь новых синонимов: Agyneta yakutsaxatilis Marusik et Koponen, 2002, syn.n. = Agyneta amersaxatilis Saaristo et Koponen, 1998; Bolyphantes palaeformis (Tanasevitch, 1989), syn.n. = Bolyphantes bipartitus (Tanasevitch, 1989), оба comb.n. (ex Lepthyphantes Menge, 1866); Epigytholus tuvensis Tanasevitch, 1996, syn.n. = Epigytholus kaszabi (Wunderlich, 1995), comb.n. (ex Lepthyphantes); Hybauchenidium holmi Marusik, 1988, syn.n. = Hybauchenidium aquilonare (L. Koch, 1879); Poeciloneta yanensis Marusik et Koponen, 2002, syn.n. = Poeciloneta variegata (Blackwall, 1841); Savignia nenilini Marusik, 1988, syn.n. = Savignia birostra (Chamberlin et Ivie, 1947); Walckenaerianus aemonicum (Deltshev, 2005), comb.n. (ex Hypomma Dahl, 1886), syn.n. = Walckenaerianus esyunini Tanasevitch, 2004. W. esyunini впервые отмечен в фауне Алтая.

\section{Introduction}

Hundreds of new taxa of the linyphiid spiders have been described during the last three decades from the territory of the former Soviet Union, mainly from the Caucasus, Siberia, the Far East and Central Asia. A significant progress in the taxonomy of the family Linyphiidae, as well as abundant material from various Palearctic regions which has been recently accumulated, allow one to not only critically consider some of the earlier described species and genera but also, in some cases, to dispel any doubts in their invalidity. The aims of the present paper are (1) to assess the validity of certain linyphiid species from the fauna of Russia and adjacent territories, and (2) to clarify their generic assignment.

\section{Material and Methods}

This paper is mainly based on the spider material kept at the Zoological Museum of the Moscow State University, Moscow, Russia (ZMMU) and the personal collection of Andrei Tanasevitch (CAT). Some types have been obtained from Museum d'histoire naturelle, Geneva, Switzerland (MHNG) and the Senckenberg Museum, Frankfurt am Main, Germany (SMF).

\section{Results}

Agyneta amersaxatilis Saaristo et Koponen, 1998 Figs 1-11.

1998 Agyneta amersaxatilis Saaristo et Koponen: 576, m \& f. 2002 A. yakutsaxatilis Marusik et Koponen, in Marusik et al.: 357, $m$ \& f, examined, syn.n.

MATERIAL EXAMINED. Agyneta yakutsaxatilis: $\sigma^{7}$ holotype (ZMMU: Ta-6538), RUSSIA, Yakutia, Yana River down flow, environs of Kular Village (70³5’N, 134³4'E), July 1996, leg. N. Vinokurov; $2 \Im^{7} \Im^{7}, 1+$ paratypes (ZMMU: Ta-6539), labeled as the holotype. 

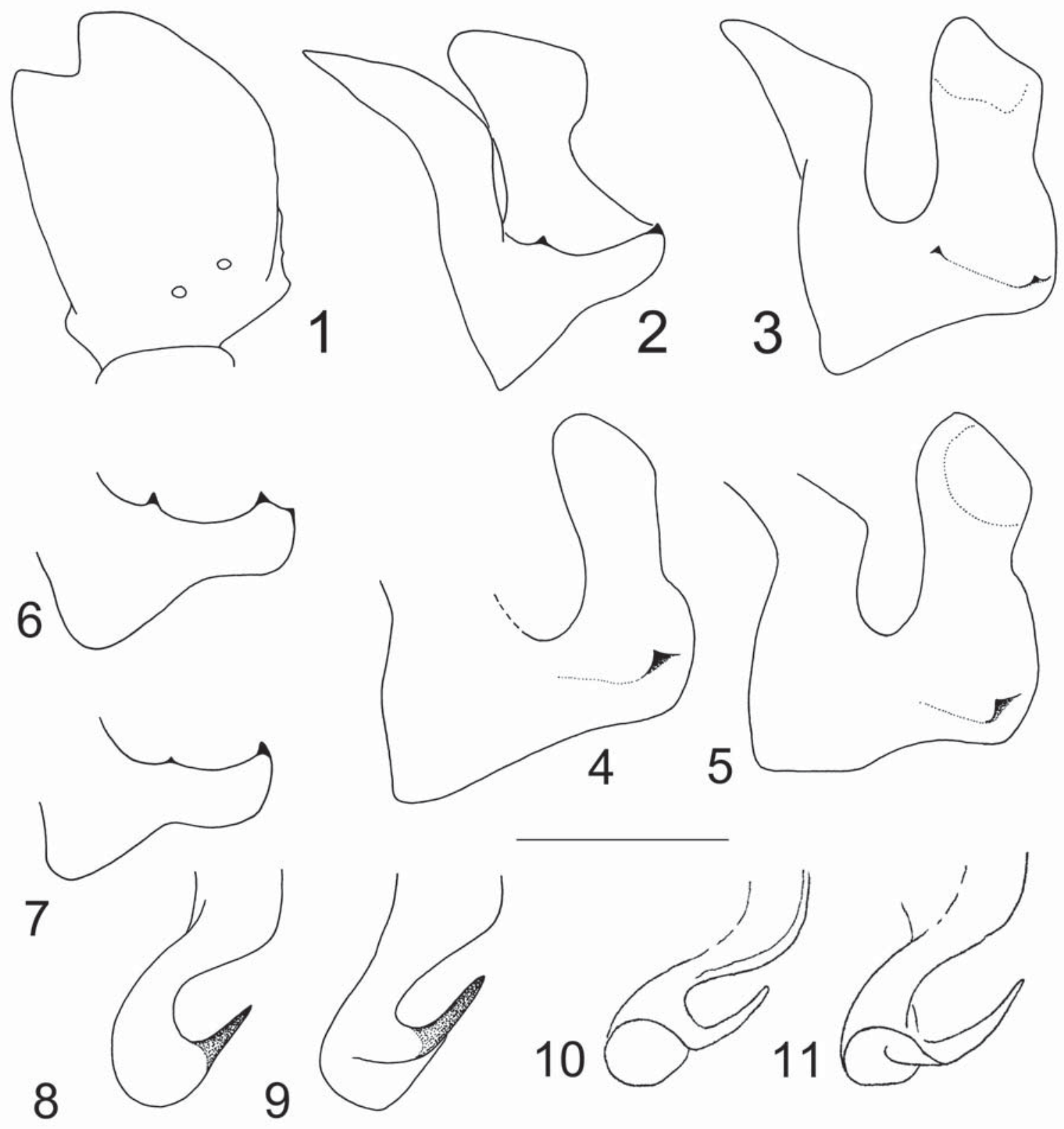

Figs 1-11. Male palp details of Agyneta yakutsaxatilis Marusik et Koponen, 2002, holotype (1-3, 6, 8), paratype (4, 5, 7, 9, 10) \& A. amersaxatilis Saaristo et Koponen, 1998, topotype (11): 1 - tibia, dorsal view; 2-5 - paracymbium; 6, 7 median part of paracymbium; 8-11 — basal part of embolus (10, 11 — after Marusik et Koponen [2002]).

Рис. 1-11. Детали строения пальпы самца Agyneta yakutsaxatilis Marusik et Koponen, 2002, голотип (1-3, 6, 8), паратип (4, 5, 7 , 9, 10) и A. amersaxatilis Saaristo et Koponen, 1998, топотип (11): 1 — голень, вид сверху; 2-5 — парацимбиум; 6, 7 — средняя часть парацимбиума; 8-11 — основание эмболюса (10, 11 — по Marusik et Koponen [2002]).

REMARKS. A. yakutsaxatilis was described from north Yakutia as a species being very similar to $A$. amersaxatilis [Marusik et al., 2002]. The authors mentioned the following diagnostic characters thereof:

1) "Yakutian species has slightly smaller size of copulatory organs". This is a very arguable statement, especially because it was based on the examination of a single specimen, the topotype of $A$. amersaxatilis; see 'Comparative material' in Marusik et al. [2002].
2) "... two species can be separated by the length of the spine of the embolic division. Its length in American species is about 0.073 [misprint, must be 0.73 ], while in A. yakutsaxatilis is about 0.57 '. These species comparison and diagnosis were also based on measuring of a single specimen, which, like in the previous case, is incorrect. The measurement of the spine length in two Yakutian specimens showed that it differs by $30 \%$ between the holotype and paratype of $A$. yakut- 

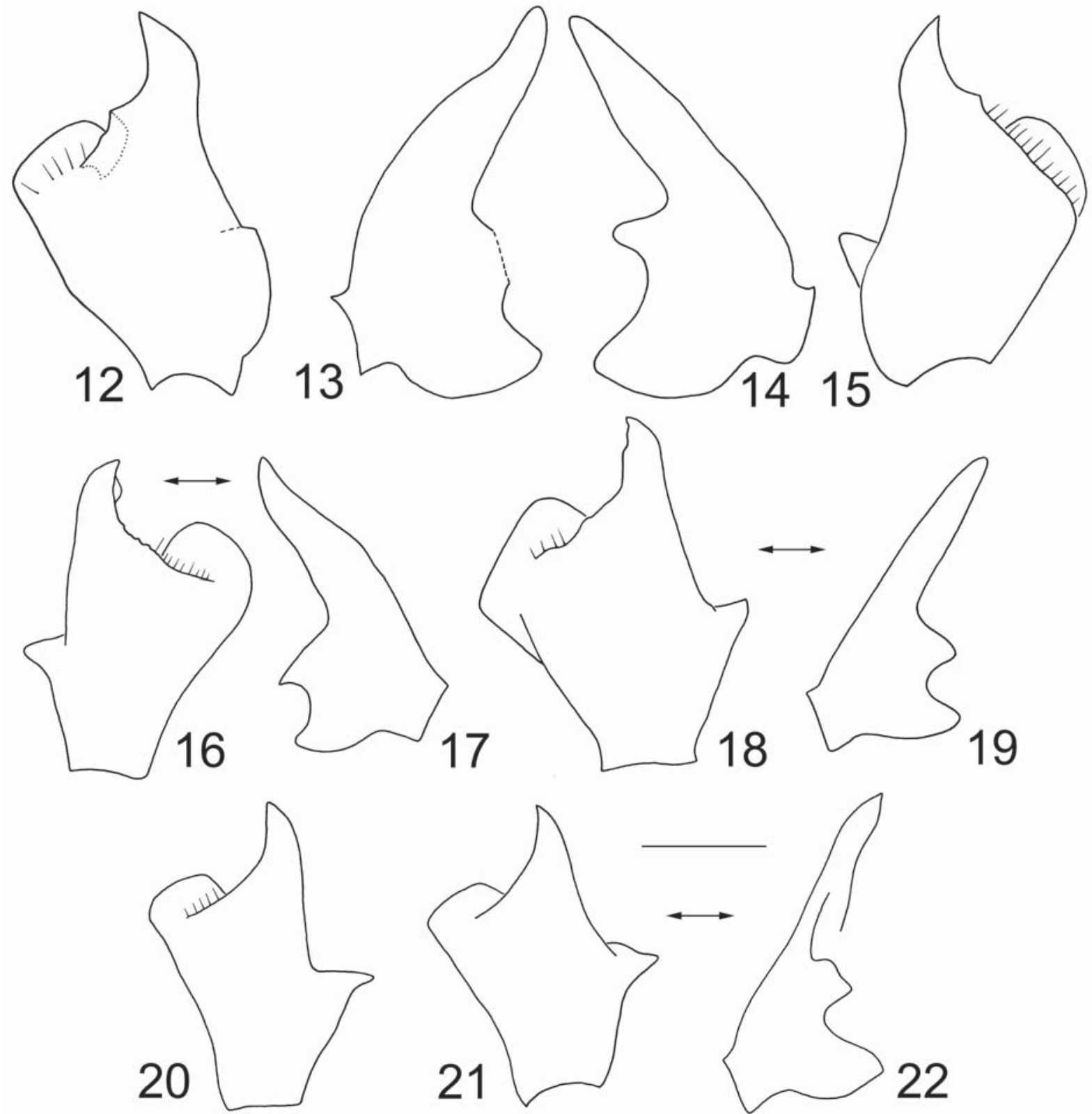

Figs 12-22. Male palpal tibia of Hybauchenidium holmi Marusik, 1988, holotype (12-15) \& H. aquilonare (L. Koch, 1879), specimens from Wrangel Island (16-22): 12, 13, 18-22 - left palp; 14-17 — right palp; 12, 15, 16, 18, 20, 21 — dorsal view; 13, 19, 22 - prolateral view; 14, 17 - retrolateral view. Arrows show the same specimen.

Рис. 12-22. Детали строения голени пальпы самца Hybauchenidium holmi Marusik, 1988, голотип (12-15) и H. aquilonare (L. Koch, 1879), экземпляр с о-ва Врангель (16-22): 12, 13, 18-22 — левая пальпа; 14-17 — правая пальпа; 12, 15, 16, 18, 20, 21 — вид сверху; 13, 19, 22 - вид спереди; 14, 17 - вид сзади. Стрелкой показан один и тот же экземпляр.

saxatilis, and this difference is even higher than stated by the authors for A. yakutsaxatilis and A. amersaxatilis (cp. Figs 8, $9 \& 10,11)$. Basically, the number and size of stylet- or tooth-shaped outgrowths at the embolus base is very variable in Agyneta Hull, 1911, Tenuiphantes Saaristo et Tanasevitch, 1996, etc., and it can considerably vary even between left and right palps of the same specimen.

3) "Yakutian species has more stridulatory ridges on male chelicera and shorter promarginal ridge...". Actually, the pattern of stridulatory fields in A. yakut- saxatilis is rather variable and not the same even on different palps in both the holotype and the paratype, whereas the number of ridges in the paratype is by a quarter higher than in the holotype, and these ridges are more widely spaced.

4) "American species has almost reduced second tooth of the down pocket, which is closely spaced with main tooth, while new species has well developed paracymbial teeth which are widely separated." In reality, the shape and position of teeth of the paracymbium 
between the holotype and the paratype of $A$. yakutsaxatilis differ as strongly as those between $A$. yakutsaxatilis and $A$. amersaxatilis (cp. Figs 2, 3, $6 \&$ 4, 5, 7): for instance, the central tooth of the paracymbium in the paratype of $A$. yakutsaxatilis is strongly reduced and virtually not seen from a perpendicular view of the paracymbium (Figs 4, 5).

Therefore, all the diagnostic characters of A. yakutsaxatilis suggested by Marusik et al. [2002] essentially reflect an individual variability. Thus, A. yakutsaxatilis should be regarded as a junior synonym of $A$. amersaxatilis.

DISTRIBUTION. Northern Yakutia (Siberia), throughout North Nearctic.

RANGE. Siberian-N-Nearctic, arcto-boreal.

\author{
Bolyphantes bipartitus (Tanasevitch, 1989), \\ comb.n.
}

1989 Lepthyphantes bipartitus Tanasevitch: 98, m, examined.

1989 L. palaeformis Tanasevitch: 106, f, examined, syn.n.

MATERIAL EXAMINED. $10^{7}, 2$ ㅇ (CAT), Kirghizia,TerskeyAlatau Mt. Ridge, Chon-Kyzylsu Valley, 2600 m, Picea forest, moss, 2.IX.1983, leg. A. Ryvkin.

REMARKS. Lepthyphantes bipartitus Tanasevitch, 1989 and Lepthyphantes palaeformis Tanasevitch, 1989 were described from opposite sexes and from different but neighboring localities in Kyrgyzstan [Tanasevitch, 1989]. Both species have been found in the same sample and it is safe to conclude that both are conspecific; besides, both species belong in fact to Bolyphantes C.L. Koch, 1837. The description of L. bipartitus precedes that of $L$. palaeformis, hence the latter name is to be considered a junior synonym.

DISTRIBUTION. The species is known from the Terskey-Alatau Mt. Ridge, N-Tien-Shang Mts.

Epigytholus kaszabi (Wunderlich, 1995), comb.n. ined.

1995 Lepthyphantes kaszabi Wunderlich: 487, m \& f, exam-

1996 Epigytholus tuvensis Tanasevitch: 69, m \& f, examined, syn.n.

MATERIAL EXAMINED. Lepthyphantes kaszabi: $10^{7}, 1$ + paratypes (SMF 60199), MONGOLIA, Bulgan aimak, $11 \mathrm{~km} \mathrm{~W}$ of Somon Bajanuur, S of Lake Bajanuur, $1000 \mathrm{~m}$, leg. Z. Kaszab, 14.VI.-24.VIII.1968, det. J. Wunderlich. Epigytholus tuvensis: O' $^{2}$ holotype (ZMMU: Ta-7097), RUSSIA, Tuva Republic, near Kyzyl, flood-lands of Yenisey River, meadow, tussocks of Achnathorum, 1.VII.1990, leg. D. Logunov; $2 O^{7} \sigma^{7}, 6$ +P paratypes (ZMMU: Ta7098), same locality, together with holotype; $3 \bigcirc^{7} \odot^{7}, 7$ 우 (CAT), 5-7 km W of Kyzyl, agrobiostation, $700 \mathrm{~m}$ a.s.l., flood-lands of Yenisei River, meadow, tussocks of Achnathorum, 15-22.V.1990, leg. D. Logunov; $20^{7} 0^{7}, 10$ 우 (ZMMU: Ta-7100), Ersin District, $20 \mathrm{~km}$ NW of Ersin, $800 \mathrm{~m}$ a.s.l., near Lake Dus-Khol, tussocks of Achnathorum, 13.VII.1989, leg. D. Logunov.

REMARKS. Lepthyphantes kaszabi Wunderlich, 1995 and Epigytholus tuvensis Tanasevitch, 1996 (the type species of the monotypic Epigytholus Tanasevitch, 1996) were described almost simultaneously: the former from Mongolia (Bulgan Aimag) [Wunderlich, 1995] and the latter from Tuva, Russia [Tanasevitch, 1996], from the locality lying close to the Mongolian one. A comparison of the type specimens of both species has revealed that they are conspecific, and Epigytholus tuvensis Tanasevitch, 1996 thus becomes a junior synonym of Epigytholus kaszabi (Wunderlich, 1995), comb.n., ex Lepthyphantes Menge, 1866.

DISTRIBUTION. Know from Tuva and Mongolia.

\section{Hybauchenidium aquilonare (L. Koch, 1879)} Figs 12-22.

1879 Erigone aquilonaris L. Koch: 42, $\mathrm{m} \& \mathrm{f}$.

1988 Hybauchenidium holmi Marusik: 1914, m \& f, examined, syn.n.

MATERIAL EXAMINED. Hybauchenidium holmi: $\sigma^{7}$ holotype (ZMMU: Ta-5689), RUSSIA, Magadan Area, upper reaches of Kolyma River, Sibit-Tyellakh River basin, $1200 \mathrm{~m}$ a.s.l., slate talus, 17.IX.1986, leg. Yu. Marusik; 4 of paratypes (ZMMU: Ta5690), 2 + + (ZMMU: Ta-5691), same date and locality, together with holotype. Hybauchenidium aquilonare: ca $50 \sigma^{7} \sigma^{7}++$, Wrangel Island, Gusikay River, 1984, leg. O. Khrulyova; ca $50 \sigma^{\top} \sigma^{\top}+0$ (ZMMU), Neizvestnaya River, pit-full traps, VIII.1983, leg. O. Khrulyova; 1 ऽ (ZMMU), W-Yakutia, $80 \mathrm{~km}$ of Kempenuyai River mouth, sweeping, 1-15.VIII.1988, leg. K. Eskov; 1 ㅇ (ZMMU), Evenkia, Taymura River basin, Chambe River, Kerbo weather station, riverside with Salix stands, 16.VIII.1981, leg. K. Eskov; 3 O $^{\top}, 4$ ㅇ (ZMMU), E-Taimyr, M. Pronchishcheva Bay, Salix stands on slope with Carex \& graminoids, 20-25.VII.1973, leg. Yu. Chernov; $2 \sigma^{\top} \sigma^{7}, 3$, 3 (ZMMU), NW-Taimyr, Ragozinka River, frost-boiled tundra with Carex, sweeping, 2.VIII.1983, leg. Yu. Chernov; 3 우 (ZMMU), W-Taimyr, Pyasina River, Kresty Village, meadow, VIII.1977, leg. Yu. Chernov.

REMARKS. The species was described from a single male and few females. An absence of the toothshaped outgrowth on the prolateral side of male palpal tibia was specified as the main diagnostic character from the closest $H$. aquilonare (L. Koch, 1879). The re-examination of the holotype of $H$. holmi has shown that this outgrowth was just broken on the left depicted palp, but it occurs on the right palp (see Figs 12-15). The other differences such as a relatively smaller size of the median plate (septum, in Marusik [1988]), as well as small differences in the shape of the dorsal and prolateral membraneous outgrowths in male palp fits well a intra-species variation range (see Figs 16-22) of $H$. aquilonare. Thus, $H$. holmi is to be treated as a junior synonym of $H$. aquilonare.

DISTRIBUTION. Tundra of the Russian Plain, throughout North Siberia, North of W-Nearctic.

RANGE. Siberian-W-Nearctic, arcto-boreal.

\section{Poeciloneta variegata (Blackwall, 1841)} Figs 23-48.

1841 Neriene variegata Blackwall: $650, \mathrm{~m} \& \mathrm{f}$

2002 Poeciloneta yanensis Marusik et Koponen, in Marusik et al.: 357, m, examined, syn.n.

MATERIAL EXAMINED. Poeciloneta yanensis: \# holotype (ZMMU: Ta-6540), RUSSIA, Yakutia, Yana River down flow, environs of Kular Village $\left(70^{\circ} 35^{\prime} \mathrm{N}, 134^{\circ} 34^{\prime} \mathrm{E}\right)$, July 1996, leg. N.N. Vinokurov. Poeciloneta variegata: 2 + $($ ZMMU), RUSSIA, Chukotka, Egvekinot, 30.VII.1988, leg. Yu. Marusik; $1 \sigma^{7}, 5$ 우 (ZMMU), 64 km N of Egvekinot, 18.VII.1988, leg. Yu. Marusik; 1 $\mathrm{O}^{\top}, 1$ (ZMMU), $130 \mathrm{~km}$ road Egvekinot - Iul'tin, canyon, 22.VI.1989, leg. Yu. Marusik; 1 (ZMMU), 121 km road Egvekinot - Iul'tin, canyon, 17.VII.1989, leg. Yu. Marusik; $1 \mathrm{O}^{7}$ (ZMMU), 

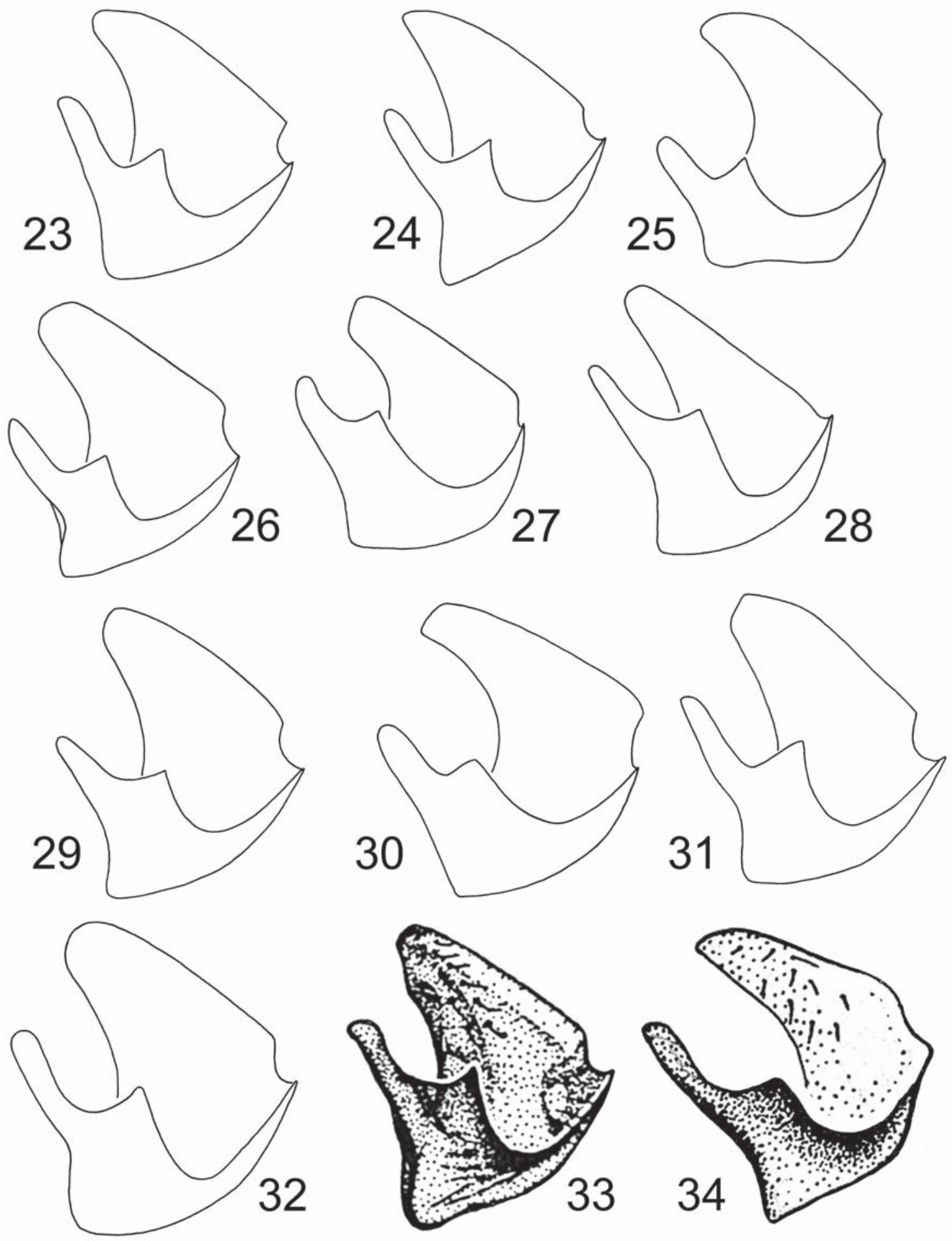

Figs 23-34. Variability of paracymbium. Poeciloneta yanensis Marusik et Koponen, 2002, holotype (23) \& P. variegata (Blackwall, 1841) (24-34): 24-27 — specimens from Chukotka; 28 - specimen from Bureya Nature Reserve; 29 - specimen from Paratunka, Kamchatka; 30 - specimen from Mirnoye, Yenisei River flow; 31 - specimen from Sivomaskinskiy, Komi Republic; 32 — specimen from Tsey, Caucasus, Republic of North Osetiya; 33 - after Roberts [1987], 34 - after Locket \& Millidge [1953], both as P. globosa, UK.

Рис. 23-34. Изменчивость парацимбиума. Poeciloneta yanensis Marusik et Koponen, 2002, голотип (23) и P. variegata (Blackwall, 1841) (24-34): 24-27 - экземпляры с Чукотки; 28 - экземпляр из Буреинского зап-ка; 29 - экземпляр с Камчатки, Паратунка; 30 - экземпляр из Мирного, Енисей; 31 - экземпляр из Коми, Сивомаскинский; 32 - экземпляр с Кавказа, Северная Осетия, Цей; 33 - по Roberts [1987], 34 — по Locket \& Millidge [1953], оба как P. globosa, Великобритания. 


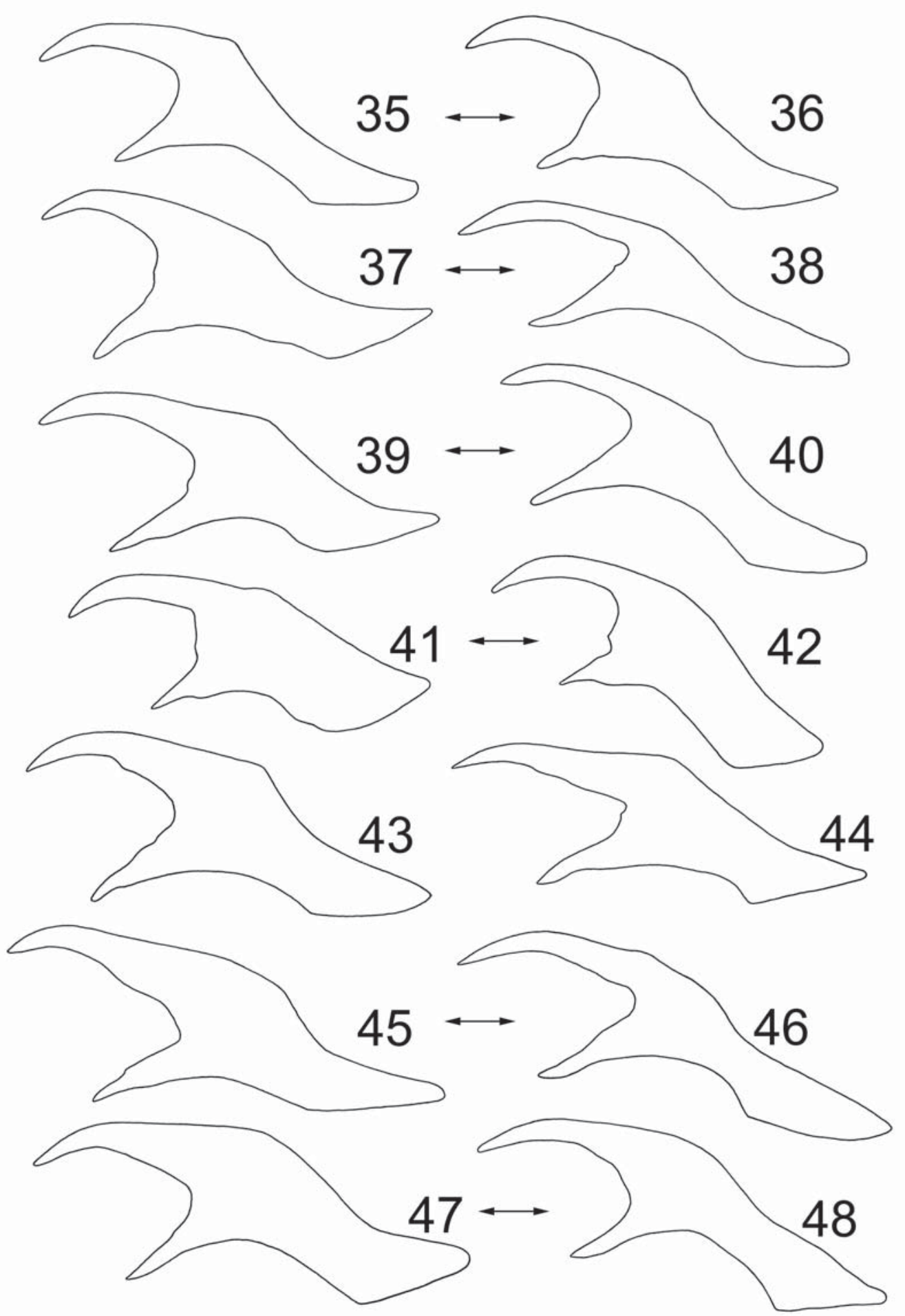

Figs 35-48. Variability of lamella characteristica (transparent part between the main branches does not shown!). Poeciloneta yanensis Marusik et Koponen, 2002, holotype (35, 36) \& P. variegata (Blackwall, 1841) (37-48): 37-40 — specimens from Chukotka; 41, 42 specimen from Bureya Nature Reserve; 43 - specimen from Paratunka, Kamchatka; 44 - specimen from Mirnoye, Yenisei River flow; 45, 46 - specimen from Sivomaskinskiy, Komi Republic; 47, 48 - specimen from Tsey, Caucasus, Republic of North Osetiya. Arrows show the same specimen.

Рис. 35-48. Изменчивость ламеллы (прозрачная часть ламеллы между ее основными ветвями не показана!). Poeciloneta yanensis Marusik et Koponen, 2002, голотип (35, 36) \& P. variegata (Blackwall, 1841) (37-48): 37-40 - экземпляры с Чукотки; 41, 42 - экземпляр из Буреинского зап-ка; 43 - экземпляр с Камчатки, Паратунка; 44 - экземпляр из Мирного, Енисей; 45, 46 экземпляр из Коми, Сивомаскинский; 47, 48 - экземпляр с Кавказа, Северная Осетия, Цей. Стрелкой показан один и тот же экземпляр. 
$13 \mathrm{~km}$ road N of Egvekinot, ravine, 27.VII.1988, leg. Yu. Marusik; 2 우 (ZMMU), Amguema River (67 $\left.03^{\circ} \mathrm{N}, 178^{\circ} 58^{\prime} \mathrm{E}\right)$, debris on slope, 22.VII.1988, leg. Yu. Marusik; 1 ○ $^{7} 2$ 우 (ZMMU), Amguema River (66 $\left.55^{\prime} \mathrm{N}, 179^{\circ} 30^{\prime} \mathrm{E}\right)$, pebble bank, near water, 20.VIII.1988, leg. Yu. Marusik; $1 \sigma^{\gamma}, 11$ क 1 (ZMMU), upper reaches of Amguema River, Vulvyveem River (67 $\left.50^{\prime} \mathrm{N}, 177^{\circ} 40^{\prime} \mathrm{E}\right)$, debris on slope, 15.VII.1989, leg. Yu. Marusik; 1 ㅇ (ZMMU), Vulvyveem River (66'55'N, 178 30'E), 13-15.VIII.1988, leg. Yu. Marusik; 1 ○', 2 우 (ZMMU), Magadan Area, upper reaches of Kolyma River, Kontaktovyi River (right tributary of Kulu River), pebble bank, $850 \mathrm{~m}$ a.s.1., 11.VIII.1986, leg. Yu. Marusik; $5 \bigcirc^{7} \sigma^{\prime}$, 6 오 (ZMMU), Kamchatka Peninsula, 30 km S Yelizovo, Paratunka, Betula forest, litter, 20.IX.1992, S. Golovatch; 1 ㅇ (CAT),

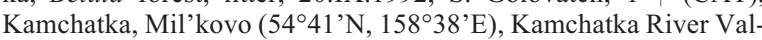
ley, Betula forest with Gramineae, in litter, 23 \& 24.VIII.1987, leg. A. Tanasevitch; $1 \sigma^{7}$ (CAT), Amurskaya Area, Norskiy Nature Reserve N.N.R., Nora River basin near Maltsevskiy cordon, in rotten wood and under bark of aspen and birch stumps, 1.IX.2004, leg. A.Ryvkin; $1 \sigma^{\top}$ (CAT), Khabarovsk Area, Bureinskiy Nature Reserve, Cordon "Strelka", 22.VII.2005, leg. L. Trilikauskas; 2 $\sigma^{7} \sigma^{7}$ (ZMMU), Krasnoyarsk Province, Yenisei River middle flow, Mirnoye Field Station $\left(62^{\circ} 46^{\prime} \mathrm{N}, 89^{\circ} \mathrm{E}\right)$, in pile of logs, 23.VIII.1978, leg. K. Eskov; 5 Oొ ${ }^{7}, 4$ 90 (ZMMU), same locality, 17.VIII.1978, leg. K. Eskov; 1 ㅇ (ZMMU), same locality, meadow, under trash, 8.VI.1978, leg. K. Eskov; 5 Oㅇ (CAT), RUSSIA, Komi Republic, Vorkuta Area, near Vorgashor Village, flat-hill peatbog, in Sphagnum, 18.VII.1982; 2 ठ $^{\top}, 9$ +o (CAT), $6 \mathrm{~km} \mathrm{NW}$ of the Sivomaskinskiy Village, sparse moss-undershrub spruce forest, in moss, 6.VII.1982; 1 フ , 1 ㅇ, $10 \mathrm{~km}$ NE Sivomaskinskiy Village, right bank of Usa River, moss-undershrub larch-birch forest on terrace, leaf litter, 3.VIII.1982; 1 (CAT), RUSSIA, Arkhangelsk Area, env. Volonga Village, $7 \mathrm{~km}$ from Volonga River mouth, rocks on steep bank slope, in crevices, among stones, 18.VII.1983; 1 7 (CAT), RUSSIA, North Caucasus, Republic of North Osetiya, Tsey Mt. Ridge, 3-4 km E of Tsey Village, $2300 \mathrm{~m}$ a.s.1., burnt-out place in Pinus forest, tall herbaceous vegetation, 16.V.1985, leg. S. Alekseev.

REMARKS. P. yanensis was described from a single male specimen, as a species being very similar to the Holarctic P. variegata [Marusik et al., 2002]. Based on the comparison of the single Yakutian male with two specimens of $P$. variegata from Finland, the authors stated the differences of $P$. yanensis, viz: small differences in the structure of paracymbium, in the shape of cymbial outgrowth and lamella characteristica. A (re)examination of numerous specimens of $P$. variegata from various localities of Eurasia (see above) has shown a high variability of the paracymbium shape (cp. Figs 23-34) and, especially, of the lamella characteristica: particularly of the length and shape of its two main branches, the width of the main body and its basal part (cp. Figs 35-48). The shape of membranized and almost transparent area between the two main branches of the lamella characteristica (not shown in Figures!) vary in each studied specimen. The shape of the cymbial outgrowth is also very variable and can vary even in different palps of the same specimen. To sum up, all the small differences of $P$. yanensis, indicated by the authors as diagnostic from $P$. variegata, lie actually within the range of variation of these characters. Therefore, $P$. yanensis should be regarded as a junior synonym of $P$. variegata.

Incidentally, I have also examined the females of $P$. variegata for variation of the epigyne and have concluded that, as with the palp components, the epigyne is highly variable as far as the shape of the pseudos- cape, stretcher, posterior median plate and lateral lobes is concern.

DISTRIBUTION. Throughout the Palaearctic, WNearctic.

RANGE. Palaearctic-W-Nearctic, polyzonal.

Savignia birostra (Chamberlin et Ivie, 1947) Figs 49-58.

1947 Cephalethus birostrum Chamberlin \& Ivie: 30, m. 1988 Savignia nenilini Marusik: 1916, ơ \& + , syn.n.

MATERIAL EXAMINED. Savignia nenilini: 1 ○, 1 우 (ZMMU), RUSSIA, Khabarovsk Area, Amursk District, Achan Village, Calamagrostis, sweeping, 22.V.1989, Kurenshchikov; 2 $\sigma^{\top} \sigma^{\top}, 6$ 우, Taimyr Autonomous Region, Putorana Plateau, env. of Lake Ayan, Kopchyug River, moss-Eriophorum bog, 11.VI.1983, leg. K. Eskov; Savignia birostra: 3 ○ ${ }^{\top}, 6$ o 6 (ZMMU), RUSSIA, Magadan Area, $26 \mathrm{~km} \mathrm{~N}$ of Magadan, Larix forest, in moss, 2.V.1986, leg. Yu.Marusik; $1 \overbrace{}^{7}$ (CAT), $29 \mathrm{~km} \mathrm{~N}$ of Magadan, Dukcha River, 3.V.1987, leg. Yu. Marusik; 2 oo (?) (CAT), Kamchatka, Kronotskiy Nature Reserve, Geysers Valley $\left(54^{\circ} 20^{\prime} \mathrm{N}\right.$, $\left.159^{\circ} 17^{\prime} \mathrm{E}\right)$, moss on thermal slope, $450 \mathrm{~m}$ a.s.1., 30.VIII.-5.IX.1987, leg. A. Tanasevitch; $1 \sigma^{7}, 2$ 오 (CAT), SW of Kamchatka, middle flow of Golygina River ( $\left.51^{\circ} 52^{\prime} \mathrm{N}, 156^{\circ} 52^{\prime} \mathrm{E}\right)$, Pinus pumila stands, in moss, 23.X.1988, leg. A. Tanasevitch; 3 of (?) (ZMMU), S of Sakhalin, Poronaysk District, middle flow of Rukutama River, 16.IV.1988, leg. A. Basarukin; $1 \sigma^{T}$ (CAT), Khabarovsk Province, Verkhnebureinskiy District, $20^{\text {th }} \mathrm{km}$ of Chegdomyn to Urgal road, mosses and plant debris on swampy bank of lake with Carex spp., graminoids, Ledum palustre, Chamaedaphne calyculata, Vaccinium uliginosum, Spiraea sp., Sphagnum spp., undergrowth of Betula platyphylla and Larix gmelinii, 6.X.2006, leg. A. Ryvkin; 3 $\Im^{7} \Im^{7}, 2$ 우 (ZMMU), Tuva Republic, 8 km upstream of mouth BiyKhem River, 11.VI.1992, leg. A. Ryvkin.

REMARKS. Regretfully, I have failed to trace the types of $S$. nenilini, which are to be kept in the ZMMU. However, I have got numerous comparative material, including topotypes, at my disposal, which has been enough to make a certain decision. S. nenilini was described from both sexes from Magadan Region [Marusik, 1988], as a species being very similar to the Siberian-Alaskan S. birostra (Chamberlin \& Ivie 1947). These species are almost indistinguishable by their copulatory organs, but, as indicated by the author, differ from each other in the shape of male carapace. Material collected from various regions of Siberia since the time of the species' description allows one to conclude that the differences in the carapace shape reflect an intra-specific variation. Moreover, there are no two discrete carapace shapes, "S. nenilini" and "S. birostra". On the contrary, there are many transitional shapes between these two forms, whereas specimens from Tuva demonstrate a third, specific "neckless" shape, somewhat different from the previous two (cp. Figs 49-58). All the small differences seen in the shape of the copulatory organs in both sexes are also either the result of variation or due to drawings made from different angles by the author (see Figs 59-66). From the above reasoning, it is safe to conclude that $S$. nenilini is a junior synonym of $S$. birostra.

The epigyne and vulva of Savignia birostra is extremely similar to that of $S$. saitoi Eskov, 1988 and $S$. zero Eskov, 1988. For their separation see Lasut et al. [2009]. 

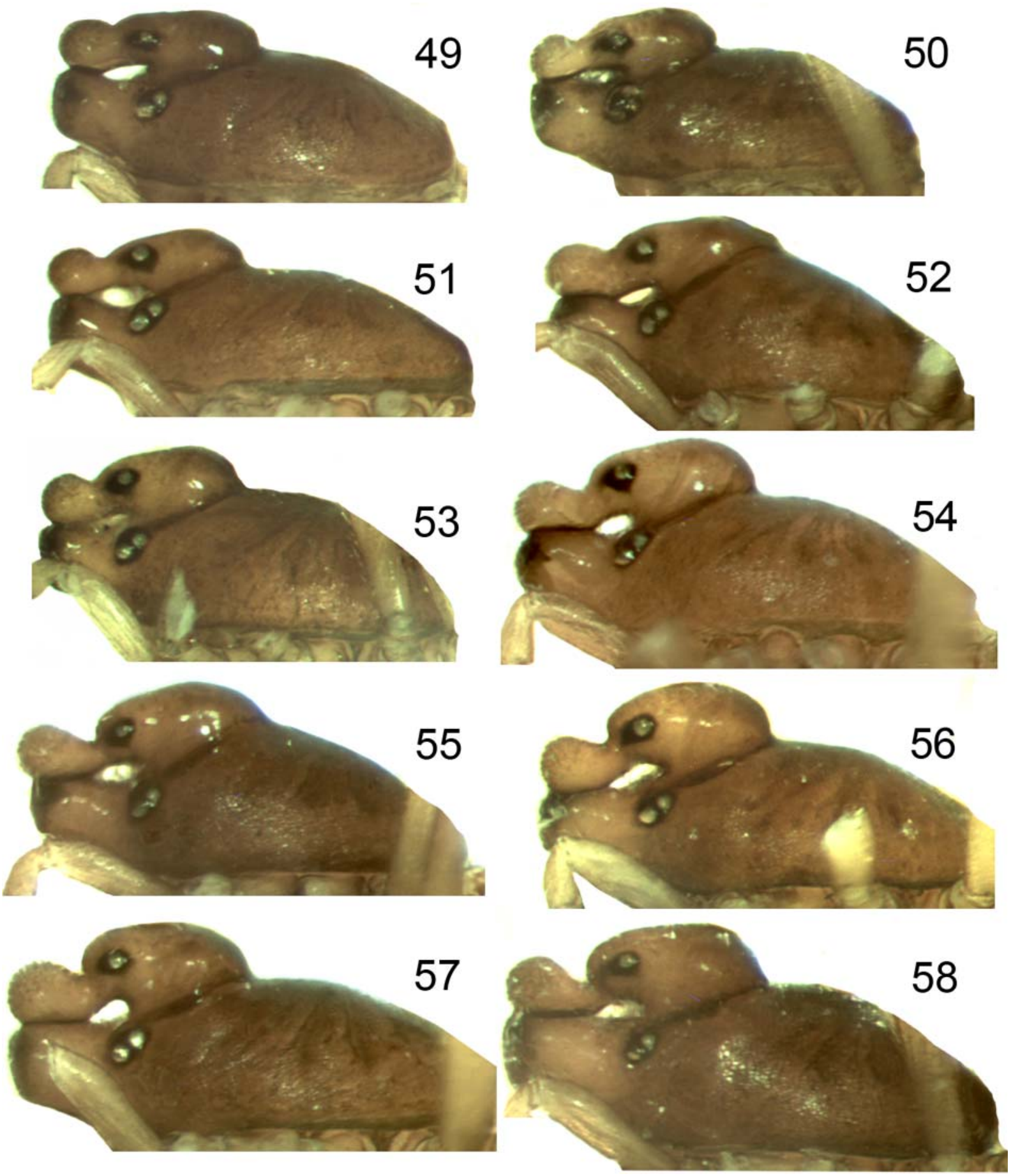

Figs 49-58. Variability of male carapace of Savignia birostra (Chamberlin et Ivie, 1947): 49, 53 — specimens from Plateau Putorana; 50 - specimen from Chegdomyn, Khabarovsk Area,; 51 - specimen from Achan, Khabarovsk Area; 52, 55 - specimens from BiyKhem, Tuva; 57 - specimen from Golygina River middle flow, Kamchatka; 54, 56, 58 - specimens from Dukcha, Magadan Area.

Рис. 49-58. Изменчивость карапакса самца Savignia birostra (Chamberlin et Ivie, 1947): 49, 53 - экземпляры с Плато Путорана; 50 - экземпляр из Хабаровского края, Чегдомын; 51 - экземпляр из Хабаровского края, Ачан; 52,55 - экземпляры из Тувы, Бий-Хем; 57 - экземпляр с Камчатки, р. Голыгина; 54, 56, 58 - экземпляры из Магаданской обл., Дукча. 


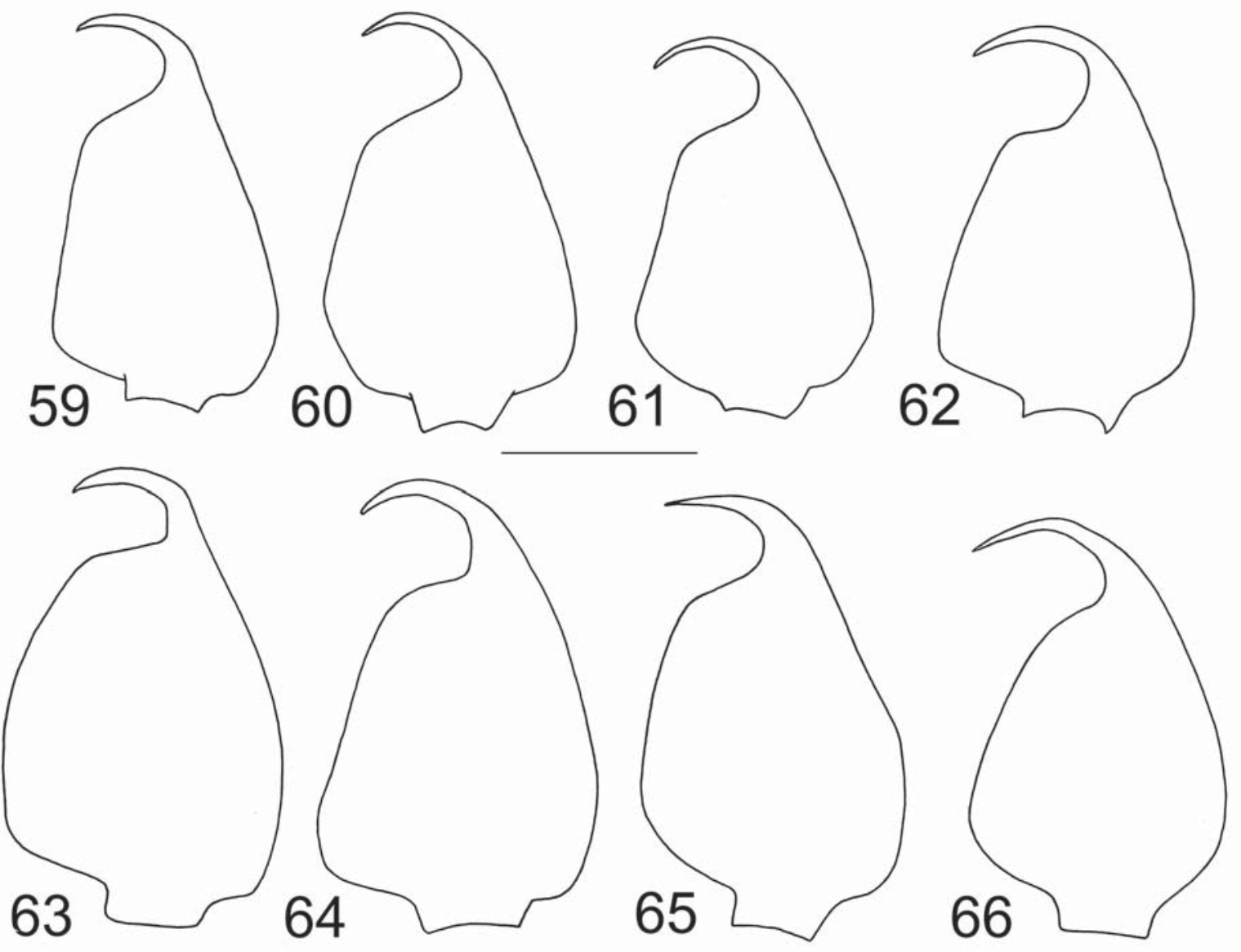

Figs 59-66. Variability of male palpal tibia of Savignia birostra (Chamberlin et Ivie, 1947): 59, 60 - specimens from Plateau Putorana; 61 - specimen from Chegdomyn, Khabarovsk Area; 62 - specimen from Achan, Khabarovsk Area; 63,64 - specimens from Dukcha, Magadan Area; 65 - specimen from Golygina River middle flow, Kamchatka; 66 - specimen from Biy-Khem, Tuva.

Рис. 59-66. Изменчивость карапакса самца Savignia birostra (Chamberlin et Ivie, 1947): 59, 60 — экземпляры с Плато Путорана; 61 - экземпляр из Хабаровского края, Чегдомын; 62 - экземпляр из из Хабаровского края, Ачан; 63, 64 - экземпляры из Магаданской обл., Дукча; 65 - экземпляр с Камчатки, р. Голыгина; 66 - экземпляр из Тувы, Бий-Хем.

DISTRIBUTION. Polar Urals, Middle, East \& South Siberia, the Russian Far East, Mongolia, China, Alaska, Yukon Territories.

RANGE: Siberian-W-Nearctic.

Walckenaerianus esyunini Tanasevitch, 2004 Figs 67-70.

1995 Oedothorax sp. - Eskov \& Marusik: 71, examined. 2004 Walckenaerianus esyunini Tanasevitch: 67, m \& f, examined.

2005 Hypomma aemonicum Deltshev: 115, m \& f, examined, syn.n.

MATERIAL EXAMINED. Hypomma aemonicum: $\sigma^{7}$ holotype (MHNG), BULGARIA, Stara Planina Mountains, Vezhen Peak (2170 $\mathrm{m}$ a.s.1.), under stones, 2.VIII.1995, leg. C. Deltshev; 2 O† paratypes (MHNG), labeled as holotype. Walckenaerianus esyunini: $\sigma^{7}$ holotype (ZMMU: Ta-7108). RUSSIA, Orenburg Province, Svetlyi District, Lake Shalkar-Ega-Kara, 16.VII-25.VIII.2002, leg. Tuneva; $2 \sigma^{7} \sigma^{7}, 17$ 우 paratypes (ZMMU: Ta-7109), labeled as holotype; $3 \sigma^{7} \sigma^{7}, 16$ + 0 (ZMMU: Ta-7110), labeled as holotype.
ADDITIONAL MATERIAL EXAMINED: 2 우 , labeled as Oedothorax sp. (ZMMU), Eastern KAZAKHSTAN (former E-Kazakhstan Area of the USSR), Zaysan District, Saur Mt. Ridge, Karaungur River (Kenderlyk River basin), riverside Populus forest, 18-22.VI.1990, leg. K. Eskov; 2 우 (CAT), RUSSIA, Altay Mountains, Chikhachyova Mt. Ridge, $3 \mathrm{~km}$ SE of Mt. Chyornaya, 2500-2800 m a.s.1., mountain tundra, 10 \& 11.VII.1996, leg. A. \& R. Dudko (a new record). This species is here reported from the Altai for the first time.

REMARKS. Walckenaerianus esyunini Tanasevitch, 2004 and Hypomma aemonicum Deltshev, 2005 were described virtually simultaneously: the first one from Orenburg Area, Russia [Tanasevitch, 2004], the second from Stara Planina Mountains, Bulgaria [Deltshev, 2005]. H. aemonicum actually belongs to the genus Walckenaerianus Wunderlich, 1995, and a detailed comparison of its copulatory organs in both sexes has shown its identity to $W$. esyunini. The shape of male carapace of the holotype $W$. aemonicus, comb.n. fits well in the variation range of $W$. esyunini, as shown 

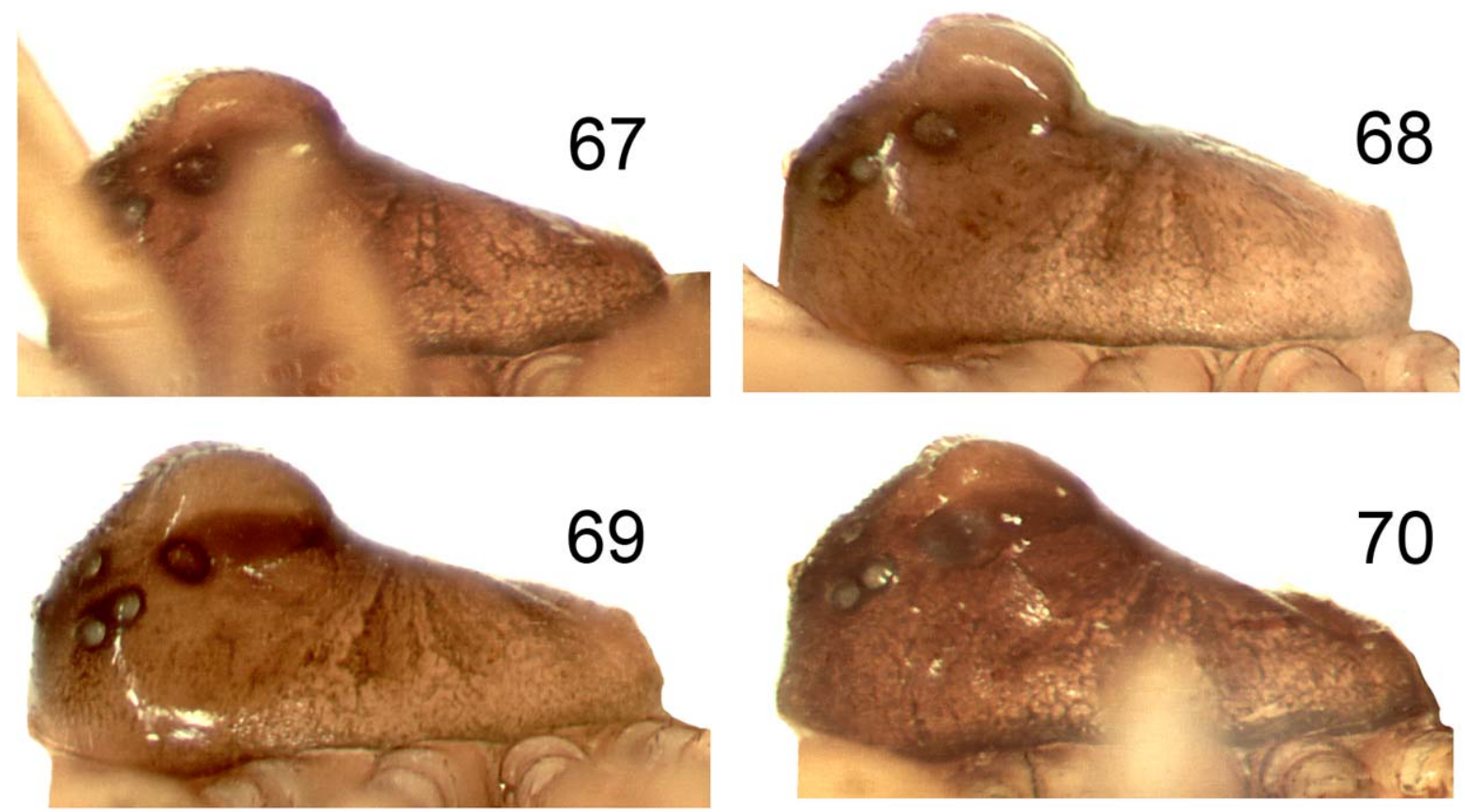

Figs 67-70. Variability of male carapace of Walckenaerianus esyunini Tanasevitch, 2004: 67 — holotype, 68-70 - paratypes from same locality as holotype.

Рис. 67-70. Изменчивость карапакса самца Walckenaerianus esyunini Tanasevitch, 2004: 67 — голотип, 68-70 - паратипы, собранные совместно с голотипом.

in Figs 67-70. Thus, the first species is to be treated as a junior synonym of $W$. esyunini.

NOTE. In the original description of $W$. esyunini, figures of the carapace, as it turned out, corresponds to the most deviated paratype [see Tanasevitch, 2004, Figs 12-14].

DISTRIBUTION. W. esyunini is known from mountains of Bulgaria (2000-2170 m a.s.l, rocky habitats) [Deltshev, 2005], from southern part of the Russian Plain, southern Urals (steppes and salines) [Tanasevitch, 2004, Esyunin, 2008], Saur Mt. Ridge (East Kazakhstan), while it was absolutely unexpectedly found in mountain tundra of Altai Mountains (see below).

ACKNOWLEDGEMENTS. I am very grateful to all persons whose collections I have examined in the present study. I wish to thank to Peter Jager and Julia Altmann (SMF), Peter J. Schwendinger (MHNG) and Kirill G. Mikhailov (ZMMU) for providing me of the type or comparative material. This study was supported in part by the Russian Foundation for Basic Research, projects \# 09-0401365-a and \# 08-04-92230-a.

\section{References}

Deltshev Ch. 2005. A new Hypomma species from Stara Planina Mountains, Bulgaria (Araneae, Linyphiidae) // Rev. suisse Zool. T.112. Fasc.1. P.115-119.

Eskov K.Yu., Marusik Yu.M. 1995. On the spiders from Saur Mt. Range, Eastern Kazakhstan (Arachnida: Araneae) // Beitr. Araneol. Bd.4 (1994). P.55-94.
Esyunin S.L. 2008. Remarks on the Ural spider (Arachnida, Aranei) fauna, 13. New records of linyphiid spider (Linyphiidae) // Arthropoda Selecta. Vol.16. No.3. P.169-172 (for 2007).

Lasut L., Marusik Yu.M., Frick H. 2009. First description of the female of the spider Savignia zero Eskov, 1988 (Araneae: Linyphiidae) // Zootaxa. No.2267. P.65-68.

Locket G.H., Millidge A.F. 1953. British spiders. Vol.2. London: Ray Society. 449 p.

Marusik Yu.M. 1988. Three new spider species of the family Linyphiidae (Aranei) from the North-East of the USSR // Zool. zhurn. Vol.67. No.12. P.1914-1918 [in Russian, with English summary].

Marusik Y.M., Koponen S., Vinokurov N.N., Nogovitsyna S.N. 2002. Spiders (Aranei) from northernmost forest-tundra of northeastern Yakutia $\left(70^{\circ} 35^{\prime} \mathrm{N}, 134^{\circ} 34^{\prime} \mathrm{E}\right)$ with description of three new species // Arthropoda Selecta Vol.10. No.3. P.351370.

Roberts M.J. 1987. The spiders of Great Britain and Ireland, Vol.2: Linyphiidae and check list. Colchester, England: Harley Books. 204 p.

Saaristo M.I., Koponen S. 1998. A review of northern Canadian spiders of the genus Agyneta (Araneae, Linyphiidae), with descriptions of two new species // Can. J. Zool. Vol.76. P.566-583.

Tanasevitch A.V. 1989. The linyphiid spiders of Middle Asia (Arachnida: Araneae: Linyphiidae) // Senckenbergiana biol. Bd.69. H.1/3. S.83-176.

Tanasevitch A.V. 1996. Two new genera of the family Linyphiidae from Tuva, South Siberia, Russia (Arachnida Aranei Linyphiidae) // Arthropoda Selecta. Vol.4 (for 1995). No.3/4. P.65-69.

Tanasevitch A.V. 2004. Two new erigonine spiders from the steppe of the East European Plain (Aranei: Linyphiidae: Erigoninae) // Arthropoda Selecta. Vol.13. No.1-2. P.63-67.

Wunderlich J. 1995. Linyphiidae aus der Mongolei (Arachnida: Araneae) // Beitr. Araneol. Bd.4. S.479-529.

Responsible editor D.V. Logunov 